International Journal of Current Microbiology and Applied Sciences ISSN: 2319-7706 Volume 10 Number 10 (2021)

\title{
Detection and Testing Pathogenicity of Xanthomonas axonopodis pv. punicae Causing Bacterial Blight on Pomegranate
}

\author{
Mahesh S. Dashyal ${ }^{*}$, M. P. Basavarajappa ${ }^{1}$, G. Manjunath ${ }^{2}$, D. P. Prakash ${ }^{3}$, \\ Sayeed Wajeed R. Mulla ${ }^{4}$ and Anita Rajkumar Ghandhe ${ }^{5}$
}

${ }^{1}$ Department of Plant Pathology, College of Horticulture, University of Horticultural Sciences Bagalkot, 587104, Karnataka, India

${ }^{2}$ Department of Plant Pathology, College of Horticulture, University of Horticultural Sciences Campus, Mysuru-571130, Karnataka, India

${ }^{3}$ Department of Fruit science, College of Horticulture, University of Horticultural Sciences Campus, Koppal, Karnataka, India

${ }^{4}$ Department of Biotechnology and Crop Improvement HREC, Vijayapur, University of Horticultural Sciences, Bagalkot 587104, Karnataka, India

${ }^{5}$ Department of Soil Science and Agriculture Chemistry, University of Horticultural Sciences, Bagalkot 587104, Karnataka, India

\section{*Corresponding author}

\section{A B S T R A C T}

\section{Keywords}

Pomegranate, bacterial blight, pathogenisity, polymerase chain reaction

Article Info

Accepted:

05 September 2021

Available Online:

10 October 2021
Pomegranate, one of the most important fruit crops, is constantly challenged by Bacterial blight caused by Xanthomonas axonopodispv. punicae, is a prevalent and destructive pomegranate disease. Accurate diagnosis of disease is very important to manage the disease. PCR have been widely used to detect or verify the presence of pathogen in recent decades. These molecular-based methods are rapid, accurate and sensitive for detecting pathogens. In this study, a primer set KKM5 and KKM6 was used and amplification of $491 \mathrm{bp}$ of $g y r B$ gene proved the presence of Xap. The pathogenicity of the Xap was confirmed following Koch's postulates.

\section{Introduction}

Pomegranate bacterial blight (PBB) occurs in many pomegranate-producing tropical and subtropical countries around the world. It is a major problem in all areas of pomegranate grown in India. For the first time in India, bacterial blight of pomegranate was reported by Hingorani and Mehta (1952). Later on during 1959, Hingorani and Singh took a thorough investigation on the disease and causal organism and designated the pathogen 
as Xanthomonas punicaesp. Nov. Chand and Kishun (1991) reported the epidemic form of disease in Bangalore caused 60 - 80 per cent loss during 1991. Later, on the basis of DNA homology, the pathogen has been renamed as Xanthomonas axonopodis pv. Punicae (Vauterin et al., 1995). The development of rapid and reliable procedures for the diagnosis of this pathogen has been a priority.

The polymerase chain reaction (PCR) allows the rapid, specific, and sensitive detection of DNA sequences and thus is ideally suited to the detection of plant pathogens. We identified Xap using Xap specific primers developed by Mondal et al., (2012) and pathogenisity of the pathogen was proved following Koch's postulates.

\section{Materials and Methods}

\section{Isolation of the pathogen}

The different parts of the pomegranate plant showing characteristic symptoms of bacterial infection were collected for isolation. Pathogen was isolated by streak plate method on NGA (nutrient glucose agar) media at $28^{\circ} \mathrm{C}$. After 48 hours of incubation individual colonies are picked and sub cultured on media. Later pure culture is stored in refrigerator at $4^{\circ}$ $\mathrm{C}$ for further use.

\section{PCR and amplification conditions}

To identify pathogen a primer set, KKM-5 Forward and KKM-6 Reverse designed by Mondal et al., (2012).Total genomic DNA from Xap was isolated from the single colony inoculated in NG broth culture grown for 72 hr at $28 \pm 0.5^{\circ} \mathrm{C}$.

Isolated DNA was quantified using the NanoDrop spectrophotometer (ND-1000, ThermoFisher, MA, USA). A primer set, KKM-5 Forward 5'GTTGATGC
TGTTCACCAGCG3' and KKM-6 Reverse 5'CATTCATTTCGCCCAAGCCC3' were designed from the $\mathrm{C}$ terminus region of gyrB gene by Monda et al., (2012b) was used for PCR-based identification of Xap. PCR amplification was performed in a $15 \mu \mathrm{l}$ reaction mix containing $100 \mathrm{ng}$ of DNA, 1X PCR Buffer, $200 \mu \mathrm{M}$ of dNTPs, $0.2 \mu$ Moles each of forward and reverse primer and $1 \mathrm{U}$ Taq DNA polymerase (Merck, Bangalore, India).

Primers were amplified with PCR cycle of initial denaturation at $94^{\circ} \mathrm{C}$ for $4 \mathrm{~min}$, then 30 cycle denaturation at $94^{\circ} \mathrm{C}$ for $60 \mathrm{sec}$, annealing for $45 \mathrm{sec}$ at $55^{\circ} \mathrm{C}$ and extension $72^{\circ} \mathrm{C}$ for 1 minute, followed by a final extension at $72^{\circ} \mathrm{C}$ for 5 minutes in a thermocycler (Eppendorfvepo protect Germany). PCR products were resolved on 1.4 per cent agarose gel using a horizontal electrophoresis system (Bio-Rad, Hercules, California, USA).

The amplified products were stained using ethidium bromide $(0.001 \mathrm{mg} / \mathrm{ml})$ and gel images were photographed using a Gel Logic 212 Pro imaging system (Gel Logic 212 PRO, Carestream, USA).

\section{Testing the pathogenicity of Xanthomonas axonopodis pv. Punicae}

Six month old Bhagwa plants raised in greenhouse conditions $\left(28 \pm 0.5{ }^{\circ} \mathrm{C}, 60-70 \%\right.$ relative humidity) were used for pathogenicity tests and for all other studies. Preparation of bacterial inoculum: Bacterial inoculum was prepared by inoculating the pure and single colony of Xap in NG broth, culture flasks were incubated at $28 \pm 0.5{ }^{\circ} \mathrm{C}$ for $72 \mathrm{hr}$ and bacterial inoculum with a minimum concentration of $0.25 \mathrm{OD}_{600} \mathrm{~nm}\left(10^{8} \mathrm{CFU} / \mathrm{ml}\right)$ was used for pathogenicity test. To check the pathogenicity of the isolate's protocols reported by Sharma et al., (2017) was followed. 


\section{Results and Discussion}

\section{Morphological characters of pathogen}

The morphological characters like its fuscan development, unique dark brown fuscan pigmentation was observed in Xap inoculated NGA medium. Its intensity increased after 7 days of incubation. Production of pigmentation is a unique character of Xap, helps in differentiating with other nonpathogenic bacteria. Colonies on NGA plates are circular, convex, mucoid, shiny and yellow were observed (Figure 1).

\section{Molecular identification of pathogen}

The molecular identification of the pathogen was established using a primer set, KKM-5 Forward and KKM-6 Reverse primers amplify gyraseB (GyrB) gene designed by Mondal et al., (2012). The primer set gave amplicon size of $491 \mathrm{bp}$, which is specific to only $X$. axonopodis pv. punicae (Figure 2).

\section{Testing the pathogenicity of pathogen}

Six month oldBhagwa plants raised in greenhouse conditions $\left(28 \pm 0.5^{\circ} \mathrm{C}, 60-70 \%\right.$ relative humidity) were used for pathogenicity test.

\section{Preparation of bacterial inoculum}

Bacterial inoculum was prepared by inoculating the pure and single colony of Xap in NGA media, incubated at $28 \pm 0.5{ }^{\circ} \mathrm{C}$ for 72 $\mathrm{hr}$ and bacterial inoculum with a minimum concentration of $0.25 \mathrm{OD}_{600} \mathrm{~nm}\left(10^{8} \mathrm{CFU} / \mathrm{ml}\right)$ was used for pathogenicity test (Plate 10). Symptoms were observed 9 days after inoculation. Initially plants shown water soaked legions on the lower leaf surface and later turned into dark brown spots surrounded by yellow hallo on leaf. From these inoculated leaves pathogen was re-isolated and compared with original culture and also confirmed using specific primers.

Phenotype based identification of Xanthomonas axonopodispv. punicae

The morphological characters like its fuscan Development, Unique dark brown fuscan pigmentation was observed in Xap inoculated NGA medium. Its intensity increases after seven days of incubation. Production of pigmentation is a unique character of Xap, helps in differentiating with other nonpathogenic bacteria. Colonies on NGA plates are circular, convex, mucoid, shiny and yellow were observed. Results of both phenotype tests were in conformity with earlier report by Mondal and Kumar (2011) and Sharma et al., (2017).

Molecular identification of Xanthomonas axonopodis pv. punicae using specific primers

To identify pathogen a primer set, KKM-5 Forward and KKM-6 Reverse designed by Mondal et al., (2012) were used for molecular detection of pathogen.

The primer set gave product size of $491 \mathrm{bp}$, which is specific to only $X$. axonopodispv. punicae (Xap). These results are in accordance with Mondal et al., (2012).

\section{Pathogenicity test}

Four month oldBhagwa plants raised in greenhouse conditions $\left(28 \pm 0.5{ }^{\circ} \mathrm{C}, 60-70 \%\right.$ relative humidity) were used for pathogenicity tests. Preparation of bacterial inoculum: Bacterial inoculum was prepared by inoculating the pure and single colony of Xap in NGA media, incubated at $28 \pm 0.5{ }^{\circ} \mathrm{C}$ for 72 $\mathrm{hr}$ and bacterial inoculum with a minimum concentration of $0.25 \mathrm{OD}_{600} \mathrm{~nm}\left(10^{8} \mathrm{CFU} / \mathrm{ml}\right)$ was used for pathogenicity test. Symptom was observed 9 days after inoculation. Initially, 
plants shown water soaked legions on the lower leaf surface and later turned into dark brown spots surrounded by yellow hallo on leaf.

From these inoculated leaves pathogen was reisolated and compared with original culture and also confirmed using specific primers.

The symptoms observed during pathogenicity and their confirmation with phenotypic expression is matching with earlier studies as reported by many workers. Hingorani and Mehta (1952) isolated the bacterial pathogen from infected pomegranate leaves and proved pathogenicity.

Infection was readily seen by them on tender leaves of the artificially inoculated plants in seven to ten days with congenial greenhouse conditions. Isolation and pathogenicity studies were also carried out in a similar fashion by Kanwar (1976).

He has observed the symptoms within four to seven days on injured portions and it took eight to twelve days to get the symptoms on uninjured parts.

A primer set, KKM-5 Forward and KKM-6 yielded the product size of $491 \mathrm{bp}$, which is specific to only $X$. axonopodispv. punicae(Xap). Morphological characters like circular, convex, mucoid, shiny and yellow colonies on NGA media were observed.

The symptoms observed during pathogenicity and their confirmation with phenotypic expression is matching with earlier studies as reported by many workers.

\section{References}

Chand, R. and Kishun, R., 1991, Studies on bacterial blight (Xanthomonas campestrispv. punicae) on pomegranate. Indian Phytopathol.,44: 370-372.

Hingorani, M. K. and Mehta, P. P., 1952, Bacterial leaf spot of pomegranate. Indian Phytopathol.,5: 55-56.

Hingorani, M. K. and Singh, J. N., 1959, Xanthomonas punicaepv. nov.on Punica granatum L. Indian J. Agr. Sci.,29: 45-48.

Kanwar, Z. S., 1976, A note on bacterial diseases of pomegranate (Punica granatum L.) in Haryana. Haryana J. Hort. Sci.,5: 177-180.

Mondal, K. K. and Kumar, A., 2011, Advances in Phenomics, Genomics and Diagnostics of Xanthomonas axonopodispv. punicea causing bacterial blight of pomegranate. IARI, New Delhi, 20-21.

Mondal, K., Rajendran, T. P., Chigurupati, P., Mani, C. and Sharma, J., 2012, The reliable and rapid polymerase chain reaction $(\mathrm{PCR})$ diagnosis for Xanthomonas axonopodispv. punicae in pomegranate. African $j$. microbial. Res.,6:5950-5956.

Sharma, J., Sharma, K. K., Kumar, A., Mondal, K. K., Thalor, S., Maity, A. and Jadhav, V. T., 2017, Pomegranate bacterial blight: symptomatology and rapid inoculation technique for Xanthomonas axonopodispv. punicae. J. Plant Pathol.,99:109-119.

Vauterin, L., Haste, B., Kersters, K. and Swings, J., 1995, Reclassification of Xanthomonas. Int. J. Syst. Bacterial.,45: 475-489.

\section{How to cite this article:}

Mahesh S. Dashyal, M. P. Basavarajappa, G. Manjunath, D. P. Prakash, Sayeed Wajeed R. Mulla and Anita Rajkumar Ghandhe. 2021. Detection and Testing Pathogenicity of Xanthomonas axonopodis pv. punicae Causing Bacterial Blight on Pomegranate. Int.J.Curr.Microbiol.App.Sci. 10(10): 43-46. doi: https://doi.org/10.20546/ijcmas.2021.1010.006 